\title{
IMPACT OF AGRICULTURAL CREDIT ACCESS ON AGRICULTURAL PRODUCTIVITY AMONG MAIZE AND RICE SMALLHOLDER FARMERS IN RWANDA
}

\author{
Nathan Kanuma Taremwa ${ }^{1 凶}$, Ibrahim Macharia ${ }^{2}$, Eric Bett ${ }^{2}$, Eucabeth Majiwa ${ }^{3}$ \\ ${ }^{1}$ University of Rwanda, Rwanda \\ ${ }^{2}$ Kenyatta University, Kenya \\ ${ }^{3}$ Jomo Kenyatta University of Agriculture and Technology, Kenya
}

\begin{abstract}
This paper assesses the impact of access to agricultural credit on the agricultural productivity of 422 smallholder farmers that cultivate maize or rice in the Western and Eastern province of Rwanda. Stratified, simple random and convenience sampling techniques were used to sample districts, sectors, cells and households. Data were collected using structured interviews and analyzed using propensity score matching techniques. Results indicated that productivity was higher by $44 \%$ among the farmers who accessed credit implying that they harvested on average an extra 440 kilograms of maize or rice. According to a crop-specific analysis, agricultural credit access had a more significant impact on maize productivity, with a difference in proportion of $68 \%(p=0.000)$ but had no impact on rice productivity $(p=0.149)$. The study concludes that agricultural credit was important for Rwanda's agricultural productivity. Thus policy measures should aim at improving smallholder farmers' access to agricultural credit and promoting the use of modern agricultural inputs, particularly among rice farmers in Rwanda.
\end{abstract}

Keywords: rice, maize, smallholder farmers, agricultural productivity, credit access, Rwanda

\section{INTRODUCTION}

Agricultural productivity is undoubtedly the cornerstone of food security given that it can guarantee food availability. The need to have substantial agricultural productivity has been currently made a priority following cognizance of the fact that by the year 2050, there will be a $70 \%$ increment in the global demand for food whose fulfillment will require $\$ 80$ billion worth of investments (World Bank, 2019). The increment in food demand is mostly related to the increase in demand for two of the most consumed cereals in the world, which are maize and rice (FAO, 2018). This has led to the focus on smallholder farmers, particularly those who cultivate maize and rice, to increase their productivity. Smallholder farmers receive attention because they constitute $80 \%$ of the 570 million farmers worldwide (World Bank, 2019 ) and contribute about $75 \%$ of global agriculture production (Devotha et al., 2019; Lowder, 2016). The focus on smallholder rice and maize farmers pertains to increasing their financial inclusion, so as to enable them to achieve higher agricultural productivity. Financial inclusion has been adopted by governments in SubSaharan Africa for the most part through increasing access to agricultural credit among rice and maize farmers (World Bank, 2019). This is because agricultural credit is recognized as a valuable instrument in the expansion of production in agribusiness (Mita et al., 2019; Lawal et al., 2019; Zakaria et al., 2019), as it aids the procurement of modern agriculture inputs like seed, equipment and labor as well.

\footnotetext{
$\bowtie$ Nathan Kanuma Taremwa, Department of Rural Development and Agricultural Economics, University of Rwanda, P.O. Box 4285, Kigali, Rwanda, e-mail: nathantaremwa@students.ku.ac.ke, https://orcid.org/0000-0003-2157-0865
} 
Taremwa, N. K., Macharia, I., Bett, E., Majiwa, E. (2021). Impact of agricultural credit access on agricultural productivity among maize and rice smallholder farmers in Rwanda. J. Agribus. Rural Dev., 1(59), 39-58. http://dx.doi.org/10.17306/ J.JARD.2021.01341

It is thus of no surprise that investments in agriculture have increased globally; for instance, in 2017 they increased by 0.5 percentage points to $2.9 \%$ of national budgetary allocations up from $2.4 \%$ in 2016 (FAO, 2018). As such, access to agricultural credit is popular especially among some smallholder maize and rice farmers (Rizwan et al., 2019; Sossou et al., 2014; Duy, 2015). However, whilst that is the case, the smallholder farmer dilemma that exists even among farmers that have access to credit is the issue of intermittent agricultural productivity, particularly of cereal (maize and rice) production. For example, the yields of cereals in Africa slightly exceed a third of the developing world average, implying that the continent accounts for only $10 \%$ of the worldwide agricultural production despite being home to 25 percent of the world's arable land (DeVries, 2017). Further still, in a cross-section of African countries, existing statistics indicate that the demand for rice exceeds the rate of its production (FAO, 2019). Enormous amounts of rice are thus being imported by many African countries to meet the demand, as exemplified by reports that Africa's food import bill ranges between $\$ 35$ and $\$ 50$ billion annually (AGRA, 2017). Africa is currently experiencing lower yields of major crops, especially cereals and tubers as compared to other regions (FAO, 2019). Additionally, maize production per hectare in Africa is 40 percent below that in developed countries (FAO, 2018), and countries such as Benin, Burkina Faso, Gambia and Niger expected to face output contractions (FAO, 2018). The Food and Agricultural Organization (2019) further reported that in countries like Zimbabwe, maize production for the year 2019 was half of their 2018 total production, while in Mozambique it was a quarter, with that of South Africa also decreasing (Sihlobo, 2019). In East Africa, it has been reported that Kenya is headed for another year of maize imports, due to a shortfall in cereal production (Andae, 2020).

The government of Rwanda has augmented agricultural sector investments, following a series of national agriculture sector development strategies over the years, including the currently implemented Strategic Plan for the Transformation of Agriculture (PSTA4). It has created a situation of more financial inclusion in Rwanda for purposes of promoting the access of smallholder farmers to micro-credit (AFR, 2017). These investments have had a significant impact (USAID, 2018) given the annual agriculture growth that has averaged over 6 percent since 2007. However, agricultural productivity in particular remains sub-optimal, especially for maize and rice, despite the fact that they are priority food crops in the country. This is exemplified by Rwanda having imported $\$ 37$ million worth of rice in 2015 , up from $\$ 31.1$ million in 2014, despite increments in farmer access to credit. As for maize production in Rwanda, available evidence shows that maize production has largely increased in the previous 10 years, although the increment has been marred with a lot of intermittences (NISR, 2019). Statistics from the Agricultural Ministry of Rwanda show that maize production increased from 357,665 tonnes to 424,204 tonnes between the years 2016 and 2017 (Muvunyi, 2019). However, the current production of maize which stands at 900,000 tonnes per annum is still not sufficient to meet the growing local demand for home consumption (Muvunyi, 2019; USAID, 2018; World Bank, 2019; NISR, 2019). That is true in the Eastern and Western provinces where the majority of cereals are produced. The same applies to rice production which, despite an increment of $15.5 \%$ as of 2018 (NISR, 2019), remains lower than its national demand which is estimated to be at 204,110 metric tons, a gap that is filled through imports (GoR), 2013). Thus Rwanda has continued to import more than 30 million dollars worth of rice to fill the local production gap (Gahigi, 2019). This is despite the fact that access to agricultural credit among farmers has been increasing. Thus, the main question that remains to be answered is whether agricultural credit has an impact on maize and rice productivity in Rwanda. It should be noted that there have been no in-country studies conducted so far to assess that impact, which proves the existence of a knowledge and research gap. To answer the question, this study evaluated the impact of agricultural credit access among smallholder farmers who cultivate rice and maize within the Eastern and Western provinces of Rwanda.

\section{THEORETICAL UNDERPINNING}

The agricultural-based economic development theory advocated by Wiggins (2006) assumes that economic development arising from agribusiness necessitates dedicated strategies that can raise the productivity and profitability of smallholder farmers. As per Wiggin's theory, agricultural credit can assume a double role in the process of economic development by enabling farmers to invest in agricultural mechanization which can lead to 
Taremwa, N. K., Macharia, I., Bett, E., Majiwa, E. (2021). Impact of agricultural credit access on agricultural productivity among maize and rice smallholder farmers in Rwanda. J. Agribus. Rural Dev., 1(59), 39-58. http://dx.doi.org/10.17306/ J.JARD.2021.01341

better agricultural productivity. Nobel in the mid-1950s also propounded the structural change theory, a theory which centers on how persons in agribusiness revolutionize their farm business from an immense dependence on the outmoded subsistence agriculture to highly modern, mechanized and advanced agricultural practices. This is achieved through substantial financial sustenance, aimed at enabling farmers to attain solid ground in their respective agricultural sectors. An extended form of the theory adds that it is literally impossible to realize the full benefits of agricultural development involving augmented productivity for smallholders unless government support systems are instated to provide the essential financial incentives and, most importantly, access to the needed credit so as to enable farmers to increase their output and raise their productivity. Thus, according to the theory, agricultural credit, when accessed by a smallholder farmer, can significantly increase agricultural productivity.

\section{LITERATURE REVIEW}

\section{West Africa}

In the literature, there are several West African studies that have investigated the impact of credit on (agricultural) productivity. Research work from Ghana supports positive relationships between microfinance and crop production; an increase of GHC1 in microcredit provision to the farmers improves their crop production by more than $33.3 \mathrm{~kg}$ (Nuhu et al., 2014). Baffoe et al. (2015) also noted significant differences in productivity between treated and non-treated farms, which they attributed to increased efficiency of the treated farmers. Similar findings were also reported in Nigeria by Awotide et al. (2015) who demonstrated that access to credit positively impacted cassava productivity. Similarly, Anang et al. (2016) compared the technical efficiency of treated and non-treated rice farmers in Ghana and found a higher level of efficiency among the former.

Akudugu (2016) also carried out a study among Ghanaian farmers and indicated that access to credit (informal and formal) augmented productivity at the household level by about $0.10 \%$. Also in Ghana, Owusu (2017) studied the impact of credit on the agricultural productivity of cassava, using three matching algorithms. Using the nearest neighbor matching technique (NNM), the author found that access to credit during the previous season increased productivity by up to 1443.76 $\mathrm{kg} / \mathrm{ha}$. When the authors used kernel-based matching (KBM), an increase of $837.19 \mathrm{~kg} / \mathrm{ha}$ was revealed. This, according to the author, also meant that cassava farmers with insufficient/without access to credit might have increased productivity by $837.19 \mathrm{~kg} / \mathrm{ha}$ as per the kernelbased matching (KBM) estimator. The radius matching (RM) technique revealed an increase of $1294.83 \mathrm{~kg} / \mathrm{ha}$ in their cassava yields among treated farmers (those who had accessed credit). The results of the three matching algorithms demonstrated significant variance in levels of cassava production at a significance level of $1 \%$.

In Nigeria, Awotide et al. (2015) studied cassava farmers and concluded that while total livestock unit and farm size of the rural households had an adverse effect in explaining the variation in cassava productivity, access to credit raised the productivity among creditbeneficiary households in Nigeria.

\section{North Africa}

In Mali, Beaman et al. (2014) also examined the returns to capital for treated and non-treated farmers and concluded that those in the treated group had higher returns, and hence productivity.

\section{Middle East}

Akram et al. (2013) conducted a study among a sample of 152 farmers in Pakistan and concluded that agricultural credit facilitated the purchase of farm input, leading to higher technical efficiency and productivity. In Pakistan, Chandio et al. (2017), and Chandio (2016) also observed that credit had a significant influence on rice productivity in the rice sector of the country. Moreover, in Pakistan, Chandio et al. (2018) further reaffirmed the effect of credit on (agricultural) productivity, reporting that both short and long-term credit had effects on wheat productivity, with the short-term credit having a stronger effect.

\section{Asia}

Zakaria et al. (2019), however, reported an inverted Ushape relationship between credit and productivity, adding that agricultural productivity first increases with an increase in credit, which is followed by a decline when credit decreases.

\section{East Africa}

In Uganda, Musinguzi (2017) used census data for the years $2008 / 2009$ to analyze the impact of credit on 
Taremwa, N. K., Macharia, I., Bett, E., Majiwa, E. (2021). Impact of agricultural credit access on agricultural productivity among maize and rice smallholder farmers in Rwanda. J. Agribus. Rural Dev., 1(59), 39-58. http://dx.doi.org/10.17306/ J.JARD.2021.01341

maize productivity, and credit was found to have increased maize production. Gonzalez and Moser (2015) noted that microfinance improves farmers' livelihood by allowing them to adopt new technologies and to purchase both higher quality and higher quantity of seeds. The author concluded that microfinance increased farmers' productivity and led to increased sales and income.

In the Rwandan context, there are few in-country studies that have evaluated the impact of credit particularly on rice and maize farmers which are two of the country's principal crops, with the exception of a study by Ali et al. (2014) which tackled the issue of credit constraints and agricultural productivity.

\section{METHODOLOGY}

\section{Study design}

A cross-sectional survey design was adopted, with which data were collected from a representative sample of smallholder farmers, and financial institution staff, all distributed over different geographical areas of Rwanda's Western and Eastern provinces. The cross-section survey design was preferred over other designs because the study was positivist in nature and had not been planned to involve the provision of real-time agricultural credit to the farmers, which may have been provided by experimental study designs. Secondly, the study was not intended to follow up with the smallholder farmers or finance institution staff, once interviewed.

\section{Study site}

The study areas were the Eastern and Western provinces of Rwanda because they comprised the majority of smallholder maize and rice farmers in Rwanda. It is estimated that in Rwanda there are 6,000,000 smallholder farmers (Maneerattana et al., 2018) of which about 3 million are found in the Eastern and Western provinces. The Eastern Province is the largest and most populous, yet the least densely populated of Rwanda's five provinces. The Eastern and Western provinces were established in early January 2006 as part of a government decentralization program that re-organized the country's local government structures. The Eastern Province comprises seven districts, namely; Nyagatare, Gatsibo, Bugesera, Kayonza, Ngoma, Kirehe, and Rwamagana, while the Western Province is also comprised of seven districts, namely; Karongi, Nyabihu, Rubavu, Rusizi,
Table 1. Summary of the districts and sectors sampled in the Eastern and Western provinces

\begin{tabular}{lll}
\hline Province & \multicolumn{1}{c}{ Districts } & \multicolumn{1}{c}{ Sectors sampled } \\
\hline Eastern & Nyagatare & Musheli and Gatunda \\
& Gatsibo & Kiramuruzi, and Murambi \\
& Bugesera & Mwogo and Juru \\
& Ngoma & Murama and Gashanda \\
& Rwamagana & Karenge, and Rubona \\
& Kirehe & Nasho, Mushikiri \\
& Kayonza & Mukarange and Nyamirama \\
Kestern & Karongi & Bwishyura, and Murambi \\
& Rutsiro & Mushubati and Kigeyo \\
& Rubavu & Nyakiliba and Rubavu \\
& Ngororero & Kavumu and Hindiro \\
& Rusizi & Bweyeye and Gashonga \\
Nyabihu & Kintobo and Bigogwe \\
Nyamasheke & Karambi and Bushenge \\
\hline
\end{tabular}

Source: own elaboration

Ngororero, Nyamasheke, and Rutsiro. For purposes of indicating the geographical composition of the provinces that formed part of the sampling frame, sectors in each of the districts in the provinces are shown in Table 1.

\section{Study population}

The target population was smallholder farmers of Eastern and Western provinces of Rwanda who were holders of less than 2.0 ha of land. The study population was particularly smallholder farmers who cultivated and harvested rice as a principal crop, or maize as a principal crop, in the previous agricultural season in Rwanda (Season B of 2019), irrespective of their credit access status. Additionally, the smallholder farmers had to have documentary evidence of the yields of rice or maize for the previous season. They also had to have documentary evidence of their application for and receipt of agricultural credit in the previous season, i.e. for those who reported that they had accessed agricultural credit for maize or rice production (Treated). Documentary evidence had to be substantiated for purposes of ensuring that data informing the independent 
Taremwa, N. K., Macharia, I., Bett, E., Majiwa, E. (2021). Impact of agricultural credit access on agricultural productivity among maize and rice smallholder farmers in Rwanda. J. Agribus. Rural Dev., 1(59), 39-58. http://dx.doi.org/10.17306/ J.JARD.2021.01341

and dependent variable were not based on self-reports which could have affected the reliability and credibility of the findings. The intervention group (factual/treated) were smallholder farmers who had accessed agricultural credit and invested it in crop production on their smallholder farms, in the season (Season B) preceding the study. This was so because, as mentioned earlier, the assessment of the impact of credit on productivity was limited to the money invested in the previous season and the possible outcome in the same season, given that productivity was also measured based on the produce of the same season. For the non-intervention (counterfactual/non-treated) group, the study included smallholder farmers who had not accessed agricultural credit for purposes of investing it in their smallholder farms in the previous season (Season B).

\section{Sample size calculation}

The formula by Krejcie and Morgan (1970) was adopted to estimate the sample sizes of smallholder maize and rice farmers in the two provinces of Rwanda (Eastern and Western). The sample size used in this study was 422 smallholder maize and rice farmers. The sample of 422 assumed a $10 \%$ probability of non-response. The sample size was calculated for smallholder farmers as follows:

$$
n=\frac{N Z^{2} P(1-P)}{(N-1) e^{2}+Z^{2} P(1-P)}
$$

where:

$N$ - the finite population size based on the assumption that the Eastern and Western provinces have an estimated 3,000,000 owners of cultivated plots of less than 2 ha (NISR, 2019)

$n$ - the required sample size

$e$ - the precision of estimate or the margin of error, set at $5 \%$

$P$ - the proportion of the attribute of interest, set at $50 \%$

$Z^{2}$ - the standard normal probability value $=1.96$.

To calculate the sample size, the parameters were substituted as follows:

$$
\begin{aligned}
& n=\frac{3,000,000(1.96)^{2}(0.5 \times 0,5)}{(3,000,000-1)(0.05)^{2}+(1.96)^{2}(0,5 \times 0,5)} \\
& n-384 \text { smallholder farmers. }
\end{aligned}
$$

In addition, given the inclusion criterion of the study (the possession of documentary evidence), non-response was expected, and to take it into account, a non-response rate of $10 \%$ was assumed. That resulted in the final sample size of $384+(384 \times 0.1)=422$ smallholder farmers.

However, the number of smallholder farmers that was required from the Eastern and Western provinces was calculated using the formula of proportioning according to size. According to the proportioning, 239 smallholder farmers were required in the Eastern Province and 183 from the Western Province. Those two population sizes were obtained using the formula of proportioning as shown below;

$$
n_{0}=\frac{N_{1} \times n}{N_{2}}
$$

where:

$n_{0}$ - number of (smallholder) farmers required for any of the two provinces

$N_{1}-$ number of (smallholder) farmers in the Eastern Province

$\mathrm{N}_{2}$ - total number of smallholder farmers available in both provinces

$n$ - sample size (422).

The number of smallholder farmers required for the Eastern Province was calculated as follows:

$n_{0}$ - smallholder farmer population required for the Eastern Province

$N_{1}$ - smallholder farmer population in the Eastern Province $=\approx 1,700,000$

$\mathrm{N}_{2}$ - total farmer (smallholder) population in both provinces $=\approx 3,000,000$

$n$ - sample size (422).

$$
n_{0}=\frac{1,700,000}{3,000,000}=422
$$

$n_{0}-239$ smallholder farmers in the Eastern Province

The number of smallholder farmers required for the Western Province was therefore $422-239=183$.

\section{Sampling procedures}

The Eastern Province comprises seven districts while the Western Province comprises five districts. To sample the study districts, a combination of stratified sampling and simple random sampling techniques was used. The two regions were stratified into two strata, 
Taremwa, N. K., Macharia, I., Bett, E., Majiwa, E. (2021). Impact of agricultural credit access on agricultural productivity among maize and rice smallholder farmers in Rwanda. J. Agribus. Rural Dev., 1(59), 39-58. http://dx.doi.org/10.17306/ J.JARD.2021.01341

i.e. Eastern (Strata 1) and Western (Strata 2), since each was composed of districts, each at the second level of administration. The districts in each stratum were sampled using simple random sampling. Simple random sampling was used to select four (4) districts from each region. Thus, in the Eastern Province, the following districts were used in the study: Nyagatare, Rwamagana, Bugesera and Gatsibo while in the Western Province, the districts of Karongi, Ngororero, Nyamasheke and Rusizi were used. This was done using a lottery where the names of the districts in each stratum were written on A6 size paper, folded and put in an opaque bag from which 4 districts were picked from the Eastern Province stratum and 4 districts from the Western Province. Each of the sampled districts was then stratified so that a representative sample of sectors in it could be sampled. A simple random sampling technique was used to select $50 \%$ of the available sectors per district.

Each of the sampled sectors was further stratified, to group each of them so as to allow for the sampling of a cross-section of the number of cells from each of them. A sample of 2 cells from each sector was obtained using a simple random sampling since sampling half of them $(>120$ cells) would have made traversing them almost infeasible. Within those cells, households were used for sampling. In this type of sampling, the principal investigator with the help of a representative of local authorities tried to establish a central point in each cell, upon which a random direction was chosen for the convenience sample of the first household to be drawn. Once a particular household was reached, the PI established rapport with the inhabitants and endeavored to establish whether the household has a member eligible for the study, after which they were interviewed. Following the sampling at the district level, the resultant sectors are shown in Table 1.

\section{Data collection methods and tools}

Whereas structured interviews were used to obtain primary data regarding credit access and agricultural productivity from the smallholder farmers, the document review method was used to verify the responses obtained in both cases.

\section{Measurement of variables}

Access to agricultural credit

Access to agricultural credit was indicated by the application for, and subsequent granting of an agricultural loan to a smallholder farmer, following which the credit obtained was invested in crop production, in the previous agricultural season.

\section{Agricultural productivity}

The productivity of the smallholder farmers was measured using the Bhatia productivity index. According to Bhatia (1967), if crop yields are considered along with their hectarage and general yield in a particular area, an account for all possible (physical and human) factors that combine to influence agricultural production becomes feasible. It is due to that holistic point of view of the index that it was used to measure agricultural productivity in this study. Further, Bhatia (1967) argues that at the same time the contribution of each crop to the overall agricultural productivity would be relative to the land percentage covered. Bhatia claims that considering exclusively yield per hectare cannot provide the true picture of the contribution and significance of a particular crop, which is a shortcoming in some other agricultural productivity assessment indices.

There may be high yields but insignificant hectarage of a crop (Bhatia, 1967), however, if a particular crop is weighted against its hectarage, agricultural productivity can be assessed and obtained in its truer sense. According to Bhatia's technique, principal crop (for instance maize and rice) yields that are chosen for each farmer are calculated as a percentage of yields in the region in which the study is conducted. The percentages are then weighted by the percentage of land under those crops. The formula for crop yield index is presented below:

$$
I Y_{\mathrm{a}}=\frac{Y C \times 100}{Y r}
$$

where:

$$
\begin{aligned}
& I Y \text { - crop "a" yield index } \\
& Y C \text { - crop "a" yield per hectare, within the area } \\
& Y r \text { - crop "a" average yield in the study area }
\end{aligned}
$$

The agricultural productivity index is provided by the formula below:

$$
\mathrm{API}=\frac{I Y_{a} \times C_{a}+I Y_{b} \times C_{b}+I Y_{c} \times C_{c} \ldots I Y_{n} \times C_{n}}{C_{a}+C_{b}+C_{c} \ldots C_{n}}
$$

where:

API - compound (composite) productivity index.

$I Y_{a}, I Y_{b} \ldots I Y_{n}$ - yields indices (per hectare) of crops $a, b \ldots n$.

$C_{a}, C_{b} \ldots C_{n}$ - percentage area under crop $a, b \ldots n$. 
In this study, agricultural productivity was considered for only a single crop (rice or maize) and not for both, for purposes of uniformity, and to eliminate the risk of data bias. It was noted that some of the farmers actually cultivated both maize and rice, which is why for such farmers, the main crop based on percentage coverage of land was considered as the principal crop. With the assumption of 1 crop per farmer, the formulae that were used were as follows;

The crop yield index was calculated using the formula:

$$
I Y_{a}=\frac{Y C \times 100}{Y r}
$$

where:

$I Y_{a}$ - crop yield index

$Y C$ - yield of crop "a" in each hectare

$\mathrm{Yr}$ - average yield of the crop in the study area, which in this study was considered as the yield of a particular crop (rice or maize) in a particular district

The agricultural productivity index for each smallholder farmer was provided by the formula below:

$$
A P I=\frac{I Y_{a} \times C_{a}}{C_{a}}
$$

where:

$A P I$ - compound (composite) productivity index

$I Y_{a}$ - yields indices (per hectare) of a partiular crop (rice or maize)

$C_{a}$ - percentage of area under crop.

According to Bhatia (1967), an index of 70 and above indicated very high productivity, an index of 60.01 to 70 indicated high productivity while an index of 50.01 to 60 was indicative of medium productivity. An index of 40.01 to 50 indicated low productivity while an index below 40 indicated very low productivity.

\section{Data management and analysis}

Data were entered in STATA 14, and then data analysis was conducted with the use of descriptive and inferential analyses. Descriptive statistics were used to describe the frequencies and percentages of each variable and attribute, for instance, the socio-demographic characteristics, access to credit, agricultural productivity and other individual or institutional characteristics.
The impact of access to credit on agricultural productivity was evaluated using Propensity score matching (PSM), a non-parametric technique commonly used to evaluate treatment effects (Caliendo and Kopeinig, 2008). That was because with Propensity score matching (PSM), the treatment effects on the treated can be calculated accurately and without bias. Since the smallholder farmers in the treatment and non-treatment groups were non-randomly selected, there would have been a risk of self-selection bias if other models, such as the logit model, or generalized linear models had been used. Therefore, since the PSM can eliminate and/ or minimize the challenge of self-selection biases that arise from non-randomization, it was an important analytical model for this part of the study. Propensity Score Matching can also effectively minimize the possibility of bias due to variances observed among treatment and control groups, although not for unobserved heterogeneity (Rosenbaum and Donald, 1983; Mendola, 2007; Becerril and Abdulai, 2010). The logit model could also be used in this impact evaluation, nevertheless, the degrees of freedom required when entering many predictor variables into a logit regression equation can, for instance, lead to Type II error (failing to detect a true difference) unless the sample size is fairly large (which is not the case in this study) (Ye and Lin, 2009). Therefore, PSM was the preferred analytical model for impact evaluation for this study since with its use, it is possible to include an infinite number of possible confounders in the course of propensity score construction. In PSM, the variables are not used as individual independent variables since they are only used to construct the score, which is why type II error is minimized. In addition, the PSM approach can enable one to examine whether the treated group and the non-treated group are fully balanced in terms of all observed potential confounders (Ye and Lin, 2009).

Secondly, there was a need to establish what the counterfactual was in order to analyze the treatment effects effectively (Baker, 2000). The counterfactual in this case referred to what could have been the case (in terms of agricultural productivity) if smallholder farmers were not treated. As such, a comparison group having comparable observable characteristics was used in order to estimate the appropriate counterfactual using the PSM technique (Friedlander and Robins, 1995). Treatment outcomes were compared by matching a comparison group (without treatment) to the treated 
Taremwa, N. K., Macharia, I., Bett, E., Majiwa, E. (2021). Impact of agricultural credit access on agricultural productivity among maize and rice smallholder farmers in Rwanda. J. Agribus. Rural Dev., 1(59), 39-58. http://dx.doi.org/10.17306/ J.JARD.2021.01341

group (with access to credit) based on the characteristics of $X$ and their propensity scores. Label $X$ referred to all covariates of credit access (Table 2).
The analysis of propensity scores was based on the logit model, after which the Nearest Neighbor Matching (NNM) algorithm was also used to estimate the Average

Table 2. Logit regression results

\begin{tabular}{|c|c|c|c|c|}
\hline Variable & $\mathrm{COR}(C I$ at $95 \%)$ & $P$ value & $\mathrm{AOR}(C I$ at $95 \%)$ & $P$ value \\
\hline 1 & 2 & 3 & 4 & 5 \\
\hline \multicolumn{5}{|l|}{ Where farmer saves money (individual) } \\
\hline In a SACCO & $2.207(0.530-9.196)$ & 0.277 & $1.508(1.048-5.855)$ & $0.027^{*}$ \\
\hline In a Commercial Bank & $4.111(2.441-10.109)$ & 0.030 & $2.389(1.745-7.976)$ & $0.022 *$ \\
\hline In a village savings scheme & $4.483(1.822-11.032)$ & 0.001 & $2.258(1.573-6.953)$ & $0.032 *$ \\
\hline In the house & $1.051(0.283-3.909)$ & 0.653 & $1.314(0.646-2.673)$ & 0.059 \\
\hline Both a SACCO and a village savings scheme & $1.410(0.315-6.310)$ & 0.407 & $0.796(0.591-1.071)$ & 0.121 \\
\hline COOPEC BK, BPR, SACCO & 1.000 & & 1.000 & \\
\hline \multicolumn{5}{|l|}{$\begin{array}{l}\text { Area of land owned during the last } 12 \text { months } \\
\text { (individual) }\end{array}$} \\
\hline $0-0.1$ ha & $0.083(0.009-0.759)$ & 0.028 & $0.127(0.022-0.748)$ & $0.023^{*}$ \\
\hline $0.1-0.19$ ha & $0.317(0.051-1.967)$ & 0.218 & $0.463(0.127-1.687)$ & 0.243 \\
\hline $0.2-0.49$ ha & $0.391(0.067-2.299)$ & 0.299 & $0.545(0.160-1.856)$ & 0.332 \\
\hline $0.5-0.99$ ha & $0.506(0.087-2.942)$ & 0.448 & $0.653(0.195-2.191)$ & 0.490 \\
\hline $1-1.99$ ha & $0.256(0.037-1.777)$ & 0.168 & $0.357(0.087-1.461)$ & 0.152 \\
\hline $2-5$ ha & 1.000 & & 1.000 & \\
\hline \multicolumn{5}{|l|}{$\begin{array}{l}\text { Have privately owned agricultural credit institu- } \\
\text { tions in the area (institutional) }\end{array}$} \\
\hline No & $0.259(0.145-0.463)$ & $0.000^{*}$ & $0.287(0.165-0.499)$ & $0.000^{*}$ \\
\hline Yes & & & 1.000 & \\
\hline \multicolumn{5}{|l|}{ Type of loans offered (institutional) } \\
\hline Long term loans only & $0.687(0.260-1.820)$ & 0.451 & $0.686(0.255-1.848)$ & 0.456 \\
\hline Short-term loans only & $0.432(0.214-0.872)$ & $0.019^{*}$ & $0.431(0.210-0.885)$ & 0.022 \\
\hline Both long term loan and short-term loans & $0.291(0.113-0.748)$ & $0.010^{*}$ & $0.290(0.112-0.750)$ & $0.011 *$ \\
\hline Short-term loans and overdrafts only & 1.000 & & 1.000 & \\
\hline \multicolumn{5}{|l|}{ Interest rate charged (institutional) } \\
\hline $1-5 \%$ & $1.974(0.960-4.058)$ & 0.065 & $1.693(0.799-3.587)$ & 0.169 \\
\hline $6-10 \%$ & $0.570(0.271-1.201)$ & 0.140 & $0.531(0.249-1.133)$ & 0.101 \\
\hline $11-15 \%$ & $0.172(0.038-0.775)$ & $0.022^{*}$ & $0.178(0.039-0.807)$ & $0.025^{*}$ \\
\hline $16-20 \%$ & $0.389(0.048-3.191)$ & 0.380 & $0.401(0.049-3.307)$ & 0.396 \\
\hline More than $20 \%$ & $3.375(0.854-13.336)$ & 0.083 & $4.812(0.630-36.738)$ & 0.130 \\
\hline Not sure & 1.000 & & 1.000 & \\
\hline
\end{tabular}


Taremwa, N. K., Macharia, I., Bett, E., Majiwa, E. (2021). Impact of agricultural credit access on agricultural productivity among maize and rice smallholder farmers in Rwanda. J. Agribus. Rural Dev., 1(59), 39-58. http://dx.doi.org/10.17306/ J.JARD.2021.01341

Table 2 cont.

\begin{tabular}{lcccc}
\hline \multicolumn{1}{c}{1} & 2 & 3 & 4 & 5 \\
\hline $\begin{array}{l}\text { Long process for obtaining agricultural credit } \\
\text { (institutional) }\end{array}$ & & & & \\
Agree & $0.752(0.362-1.562)$ & 0.444 & $0.770(0.406-1.461)$ & 0.425 \\
Disagree & $2.434(1.114-5.318)$ & $0.026^{*}$ & $2.026(1.073-3.824)$ & $0.029^{*}$ \\
Don't know & 1.000 & & 1.000 & \\
Repayment terms (institutional) & & & & 0.854 \\
In full only & $0.222(0.029-1.684)$ & 0.146 & $0.884(0.238-3.279)$ & 0.735 \\
Installment only & $0.170(0.023-1.263)$ & 0.083 & $0.831(0.283-2.438)$ \\
Don't know & $0.118(0.015-0.911)$ & $0.040^{*}$ & $0.203(0.045-0.922)$ & $0.039^{*}$ \\
Both in full and installment & 1.000 & & 1.000 & \\
\hline
\end{tabular}

Source: own elaboration

Treatment Effect on the Treated (ATET). Given that $\mathrm{Y}_{1}$ symbolizes the potential result following treatment and $\mathrm{Y}_{0}$ symbolizes the potential resultant condition in the case of non-treatment, the impact of the intervention is given by:

$$
\Delta=Y_{1}-Y_{0}
$$

\section{Estimating the propensity score (PS)}

According to Rosenbaum and Rubin (1983), the propensity score refers to the probability of obtaining treatment in light of a given set of pre-treatment characteristics. In this study, that probability (propensity score) was computed using the binary logit regression model, which is given as;

$$
P(X)=\operatorname{Pr}\{D=1 / X\}=E\{D / X\}
$$

where:

$D-(0,1)$ indicates the characteristics of treatment (dependent variable) which in this study was access to credit. That is, $D=1$ if credit is accessed (treated) and $D=0$ if no credit is accessed (not treated)

$X$ - represents the possible determinants for a farmer to be treated, which included: where farmer saves money, area of land owned, availability of privately owned agricultural credit institutions in the area, type of loans offered by the institutions, the interest rate charged, duration of the process for obtaining agricultural credit, and repayment terms.
Matching the unit using the propensity score Following the estimation of propensity scores, definite matching was conducted in which the average treatment effects on the treated (ATET) (the counterfactual) was applied using the nearest neighbor matching method.

Impact analysis (ATET)

The average treatment effect on the treated (impact) was estimated as follows:

$$
\begin{aligned}
A T T & =E(\Delta \mid D=1, X) \\
& =E(Y 1-Y 0 \mid D=1, X) \\
& =(Y 1 \mid D=1, X)-E(Y 0 \mid D=1, X)
\end{aligned}
$$

where:

$D-1$ indicated treatment

$X$ - a set of covariates on which the smallholder farmers were matched.

\section{RESULTS}

\section{Demographic and socioeconomic characteristics of the farmers}

This section presents the findings related to the impact of credit access on agricultural productivity. However, prior to impact assessment, descriptive statistics of variables related to treatment and productivity dynamics for maize and rice farmers are first presented respectively, since these were later used in the crop-specific analysis of the impact of access to agricultural credit on productivity. Table 3 provides descriptive statistics of the profiles of the interviewed smallholder farmers. 
Taremwa, N. K., Macharia, I., Bett, E., Majiwa, E. (2021). Impact of agricultural credit access on agricultural productivity among maize and rice smallholder farmers in Rwanda. J. Agribus. Rural Dev., 1(59), 39-58. http://dx.doi.org/10.17306/ J.JARD.2021.01341

Table 3. Demographic and socioeconomic characteristics of the farmers

\begin{tabular}{|c|c|c|c|}
\hline & \multicolumn{2}{|c|}{ Farmer category } & \multirow[b]{2}{*}{ Total } \\
\hline & $\begin{array}{l}\text { rice farmer } \\
n=125\end{array}$ & $\begin{array}{c}\text { maize farmer } \\
n=297\end{array}$ & \\
\hline \multicolumn{4}{|l|}{ Gender } \\
\hline Female & $50(40.0 \%)$ & $124(41.8 \%)$ & $174(41.2 \%)$ \\
\hline Male & $75(60.0 \%)$ & $173(58.2 \%)$ & $248(58.8 \%)$ \\
\hline \multicolumn{4}{|l|}{ Received formal education } \\
\hline No & $22(17.6 \%)$ & $45(15.2 \%)$ & $67(15.9 \%)$ \\
\hline Yes & $103(82.4 \%)$ & $252(84.8 \%)$ & $355(84.1 \%)$ \\
\hline \multicolumn{4}{|l|}{ Level of education received } \\
\hline Primary (lower) & $32(30.5 \%)$ & $73(29.2 \%)$ & $105(29.6 \%)$ \\
\hline Primary (upper) & $58(55.2 \%)$ & $143(57.2 \%)$ & $201(56.6 \%)$ \\
\hline Secondary (O level) & $5(4.8 \%)$ & $19(7.6 \%)$ & $24(6.8 \%)$ \\
\hline Secondary (A level) & $10(9.5 \%)$ & $9(3.6 \%)$ & $19(5.4 \%)$ \\
\hline Post-secondary education & $0(0.0 \%)$ & $2(0.8 \%)$ & $2(0.6 \%)$ \\
\hline University education & $0(0.0 \%)$ & $4(1.6 \%)$ & $4(1.1 \%$ \\
\hline \multicolumn{4}{|c|}{ Duration as a smallholder farmer } \\
\hline One year & $4(3.2 \%)$ & $3(1.0 \%)$ & $7(1.7 \%)$ \\
\hline Two years & $1(0.8 \%)$ & $1(0.3 \%)$ & $2(0.5 \%)$ \\
\hline Three years & $5(4.0 \%)$ & $5(1.7 \%)$ & $10(2.4 \%)$ \\
\hline Four years & $1(0.8 \%)$ & $3(1.0 \%)$ & $4(0.9 \%)$ \\
\hline Five years & $6(4.8 \%)$ & $17(5.7 \%)$ & $23(5.5 \%)$ \\
\hline Above five years & $108(86.4 \%)$ & $268(90.2 \%)$ & $376(89.1 \%)$ \\
\hline \multicolumn{4}{|l|}{ Access to credit } \\
\hline Accessed & $20(16.0 \%)$ & $42(14.1 \%)$ & $62(14.7 \%)$ \\
\hline Not accessed & $105(84.0 \%)$ & $255(85.9 \%)$ & $360(85.3 \%)$ \\
\hline \multicolumn{4}{|c|}{ Other sources of income besides smallholder farming } \\
\hline No & $98(78.4 \%)$ & $242(81.5 \%)$ & $340(80.6 \%)$ \\
\hline Yes & $27(21.6 \%)$ & $55(18.5 \%)$ & $82(19.4 \%)$ \\
\hline
\end{tabular}

Source: own elaboration.

The findings in Table 3 above show that the majority of rice $(60.0 \%)$ and maize farmers $(58.2 \%)$ were men. More than two-thirds of the rice $(82.4 \%)$ and maize farmers $(84.8 \%)$ reported that they had received a formal education, and among those, more than half of them had received primary (upper) education, at $55.2 \%$ and
$57.2 \%$ for rice and maize farmers respectively. Among the rice farmers, more than four-fifths of them (86.4\%) had work experience of more than five years in smallholder farming, while among maize farmers more than fourfifths $(90.2 \%)$ had smallholder farming work experience of more than five years. More than three-quarters 
Taremwa, N. K., Macharia, I., Bett, E., Majiwa, E. (2021). Impact of agricultural credit access on agricultural productivity among maize and rice smallholder farmers in Rwanda. J. Agribus. Rural Dev., 1(59), 39-58. http://dx.doi.org/10.17306/ J.JARD.2021.01341

Table 4. Agricultural productivity levels of the rice and maize farmers

\begin{tabular}{|c|c|c|c|}
\hline & \multicolumn{2}{|c|}{ Farmer category } & \multirow[b]{2}{*}{ Total } \\
\hline & $\begin{array}{c}\text { rice farmer } \\
n=125\end{array}$ & $\begin{array}{c}\text { maize } \\
\text { farmer } \\
n=297\end{array}$ & \\
\hline \multicolumn{4}{|c|}{ Agricultural productivity index } \\
\hline $\begin{array}{l}70.01 \text { and above } \\
\text { (very high) }\end{array}$ & $\begin{array}{c}4 \\
(25.0 \%)\end{array}$ & $\begin{array}{c}12 \\
(75.0 \%)\end{array}$ & $\begin{array}{c}16 \\
(100.0 \%)\end{array}$ \\
\hline $\begin{array}{l}60.01 \text { to } 70.00 \\
\text { (high) }\end{array}$ & $\begin{array}{c}32 \\
(31.4 \%)\end{array}$ & $\begin{array}{c}70 \\
(68.6 \%)\end{array}$ & $\begin{array}{c}102 \\
(100.0 \%)\end{array}$ \\
\hline $\begin{array}{l}50.01 \text { to } 60.00 \\
\text { (medium) }\end{array}$ & $\begin{array}{c}12 \\
(32.4 \%)\end{array}$ & $\begin{array}{c}25 \\
(67.6 \%)\end{array}$ & $\begin{array}{c}37 \\
(100.0 \%)\end{array}$ \\
\hline $\begin{array}{l}0.01 \text { to } 50.00 \\
\text { (low) }\end{array}$ & $\begin{array}{c}33 \\
(31.1 \%)\end{array}$ & $\begin{array}{c}73 \\
(68.9 \%)\end{array}$ & $\begin{array}{c}106 \\
(100.0 \%)\end{array}$ \\
\hline $\begin{array}{l}40.00 \text { and below } \\
\text { (very low) }\end{array}$ & $\begin{array}{c}44 \\
(27.3 \%)\end{array}$ & $\begin{array}{c}117 \\
(72.7 \%)\end{array}$ & $\begin{array}{c}161 \\
(100.0 \%)\end{array}$ \\
\hline \multicolumn{4}{|l|}{ Productivity } \\
\hline $\begin{array}{l}\text { Optimal productivity } \\
(\text { API }>60)\end{array}$ & $\begin{array}{c}40 \\
(33.9 \%)\end{array}$ & $\begin{array}{c}78 \\
(66.1 \%)\end{array}$ & $\begin{array}{c}118 \\
(100.0 \%)\end{array}$ \\
\hline $\begin{array}{l}\text { Sub-optimal productivity } \\
(\text { API }<60)\end{array}$ & $\begin{array}{c}85 \\
(28.0 \%)\end{array}$ & $\begin{array}{c}219 \\
(72.0 \%)\end{array}$ & $\begin{array}{c}304 \\
(100.0 \%)\end{array}$ \\
\hline
\end{tabular}

Source: own elaboration. of the rice farmers $(84 \%)$ and more than two-thirds of the maize farmers $(85.9 \%)$ had not accessed agricultural credit. More than two-thirds of the rice farmers $(78.4 \%)$ and maize farmers $(81.5 \%)$ had other sources of income besides agribusiness.

Table 4 above shows the agricultural productivity indices and productivity levels of rice and maize farmers. It is shown that among the rice farmers, almost a third of them had a medium agricultural productivity index (50.01 to 60.0) (32.4\%), while three-quarters of the maize farmers had a very high agricultural productivity index (70.01 and above). Close to a third of the rice farmers had optimal productivity (33.9\%), and slightly above two-thirds of the maize farmers had optimal productivity (66.1\%).

Table 5 above shows the agricultural productivity dynamics of rice and maize among the smallholder farmers who participated in this study, analyzed against treatment characteristics for both farmer groups. Among rice farmers who had accessed agricultural credit, a quarter of them $(25.0 \%)$ had medium agricultural productivity indices, while more than a third of the maize farmers had low API (42.9\%). Sub-optimal productivity was characteristic of the majority of the rice farmers (API < 60) $(70 \%)$, and almost half of the maize farmers.

Table 5. Agricultural productivity and agricultural credit access among rice and maize farmers

\begin{tabular}{|c|c|c|c|c|c|}
\hline \multicolumn{3}{|c|}{ Rice farmer credit access } & \multicolumn{3}{|c|}{ Rice farmer credit access } \\
\hline $\begin{array}{l}\text { Agricultural productivity } \\
\text { index }\end{array}$ & $\begin{array}{c}\text { Accessed credit } \\
\quad n=20\end{array}$ & $\begin{array}{l}\text { Did not access } \\
\text { credit } n=105\end{array}$ & $\begin{array}{l}\text { Agricultural productivity } \\
\text { index }\end{array}$ & $\begin{array}{c}\text { Accessed credit } \\
\quad n=42\end{array}$ & $\begin{array}{l}\text { Did not access } \\
\text { credit } n=255\end{array}$ \\
\hline 70.01 and above (very high) & $1(16.7 \%)$ & $5(83.3 \%)$ & 70.01 and above (very high) & $0(0.0 \%)$ & $10(3.9 \%)$ \\
\hline 60.01 to 70.00 (high) & $7(18.4 \%)$ & $31(81.6 \%)$ & 60.01 to 70.00 (high) & $8(19.0 \%)$ & $59(23.1 \%)$ \\
\hline 50.01 to 60,00 (medium) & $3(25.0 \%)$ & $9(75.0 \%)$ & 50.01 to 60,00 (medium) & $4(9.5 \%)$ & $22(8.6 \%)$ \\
\hline 0.01 to 50.00 (low) & $1(4.0 \%)$ & $24(96.0 \%)$ & 0.01 to 50.00 (low) & $12(28.6 \%)$ & $58(22.7 \%)$ \\
\hline 40.00 and below (very low) & $8(18.2 \%)$ & $36(81.8 \%)$ & 40.00 and below (very low) & $18(42.9 \%)$ & $106(41.6 \%)$ \\
\hline Productivity levels & $\begin{array}{c}\text { Accessed credit } \\
\quad n=20\end{array}$ & $\begin{array}{l}\text { Did not access } \\
\text { credit } n=105\end{array}$ & Productivity levels & $\begin{array}{l}\text { Accessed credit } \\
\quad n=42\end{array}$ & $\begin{array}{l}\text { Did not access } \\
\text { credit } n=255\end{array}$ \\
\hline $\begin{array}{l}\text { Optimal productivity } \\
(\text { API }>60)\end{array}$ & $6(30.0 \%)$ & $31(29.5 \%)$ & $\begin{array}{l}\text { Optimal productivity } \\
(\text { API }>60)\end{array}$ & $22(52.4 \%)$ & $66(25.9 \%)$ \\
\hline $\begin{array}{l}\text { Suboptimal productivity } \\
\text { (API < 60) }\end{array}$ & $14(70.0 \%)$ & $74(70.5 \%)$ & $\begin{array}{l}\text { Sub-optimal productivity } \\
\text { (API < 60) }\end{array}$ & $20(47.6 \%)$ & $189(74.1 \%)$ \\
\hline
\end{tabular}

Source: own elaboration. 
Taremwa, N. K., Macharia, I., Bett, E., Majiwa, E. (2021). Impact of agricultural credit access on agricultural productivity among maize and rice smallholder farmers in Rwanda. J. Agribus. Rural Dev., 1(59), 39-58. http://dx.doi.org/10.17306/ J.JARD.2021.01341

Table 6. Average treatment effects analysis using propensity score (PS) and nearest neighbor matching (NNM)

\begin{tabular}{|c|c|c|c|c|c|c|}
\hline \multicolumn{7}{|c|}{ Propensity score matching estimator } \\
\hline \multirow[t]{2}{*}{$\begin{array}{l}\text { Average treatment } \\
\text { effect (ATE) }\end{array}$} & Agricultural productivity & Coef. & $\begin{array}{l}\text { AI. robust } \\
\text { Std. err }\end{array}$ & $\mathrm{Z}$ & $P>|z|$ & ( $95 \%$ conf. interval) \\
\hline & $\begin{array}{l}\text { Not accessed } \\
\text { vs Accessed credit }\end{array}$ & 0.43 & 0.09 & 4.51 & 0.000 & $0.24-0.6$ \\
\hline \multicolumn{7}{|c|}{ Nearest neighbor matching estimator } \\
\hline \multirow[t]{2}{*}{$\begin{array}{l}\text { Average treatment } \\
\text { effect (ATE) }\end{array}$} & Agricultural productivity & Coef. & $\begin{array}{l}\text { AI. robust } \\
\text { Std. err }\end{array}$ & $\mathrm{Z}$ & $P>|z|$ & ( $95 \%$ conf. interval) \\
\hline & $\begin{array}{l}\text { Not accessed } \\
\text { vs Accessed credit }\end{array}$ & 0.44 & 0.08 & 5.65 & 0.000 & $0.29-0.60$ \\
\hline
\end{tabular}

Source: own elaboration.

Table 6 above shows the findings obtained from the analysis of ATET using both the propensity score and nearest neighbor matching estimators. Propensity score matching and nearest neighbor matching scores were in agreement with the fact that agricultural productivity was higher among smallholder farmers who had accessed agricultural credit during the previous crop season. Thus, the general average treatment effect was 0.43 for PSM and 0.44 for NNM, implying that agricultural productivity among the treated smallholder farmers was 0.4 times higher than that of the non-treated smallholder farmers.

In Table 7 above, findings pertaining to the average treatment effect on the treated are shown in both generic terms (population) and specific terms (treated). There are slight differences in treatment coefficients between ATE and ATET findings, given that both estimations from PSM and NNM for ATE and ATET revealed that agricultural productivity among the treated smallholder farmers was 0.4 times higher $(0.4359756)$ than that of the non-treated smallholder farmers. The difference in proportions between the treated and non-treated maize farmers (those who accessed and did not access credit) was $44 \%$ (coef. $=0.44$ ), implying that for every tonne of maize produced by the non-treated farmers, $44 \%$ more $(440 \mathrm{~kg})$ were produced by the treated farmers. In other words, for every tonne of either rice or maize produced by the non-treated smallholder farmers, the treated smallholder farmers produce an extra 440 kilograms.

Table 7. Average treatment effects on the treated (ATET)

\begin{tabular}{|c|c|c|c|c|c|c|}
\hline \multicolumn{7}{|c|}{ Propensity score matching estimator } \\
\hline $\begin{array}{l}\text { Average treatment effect } \\
\text { on the treated (ATET) }\end{array}$ & Agricultural productivity & Coef. & $\begin{array}{l}\text { AI. robust } \\
\text { Std. err }\end{array}$ & $\mathrm{Z}$ & $P>|z|$ & [95\% conf. interval] \\
\hline & $\begin{array}{l}\text { Non-Treated Smallholder farmers } \\
\text { Versus: Treated Smallholder farmers }\end{array}$ & 0.41 & 0.11 & 3.82 & 0.000 & $0.20-0.62$ \\
\hline \multicolumn{7}{|c|}{ Nearest neighbor matching estimator } \\
\hline & Access to agricultural credit & Coef. & $\begin{array}{l}\text { AI. robust } \\
\text { Std. Err }\end{array}$ & Z & $\mathrm{P}>|\mathrm{z}|$ & ( $95 \%$ conf. interval \\
\hline & $\begin{array}{l}\text { Non treated smallholder farmers } \\
\text { Versus: Treated smallholder farmers }\end{array}$ & 0.44 & 0.84 & 5.32 & 0.000 & $0.28-0.60$ \\
\hline
\end{tabular}

Source: own elaboration. 
Taremwa, N. K., Macharia, I., Bett, E., Majiwa, E. (2021). Impact of agricultural credit access on agricultural productivity among maize and rice smallholder farmers in Rwanda. J. Agribus. Rural Dev., 1(59), 39-58. http://dx.doi.org/10.17306/ J.JARD.2021.01341

Table 8. Average treatment effects (ATE) using propensity score (PS) for the productivity of rice farmers and maize farmers

\begin{tabular}{|c|c|c|c|c|c|c|}
\hline \multicolumn{7}{|c|}{ Propensity score matching estimator } \\
\hline \multirow{2}{*}{$\begin{array}{l}\text { Average treatment effect } \\
\text { (ATE) } \\
\text { Rice }\end{array}$} & Rice productivity & Coef. & $\begin{array}{l}\text { AI. robust } \\
\text { Std. err }\end{array}$ & $Z$ & $P>|z|$ & ( $95 \%$ conf. interval) \\
\hline & $\begin{array}{l}\text { Non-treated rice farmers } \\
\text { Versus: Treated rice farmers }\end{array}$ & 0.09 & 0.12 & 0.80 & 0.424 & $-0.14-0.80$ \\
\hline \multirow{2}{*}{$\begin{array}{l}\text { Average treatment effect } \\
\text { (ATE) } \\
\text { Maize }\end{array}$} & & Coef. & $\begin{array}{l}\text { AI. robust } \\
\text { Std. err }\end{array}$ & $Z$ & $P>|z|$ & ( $95 \%$ conf. interval) \\
\hline & $\begin{array}{l}\text { Non-treated maize farmers } \\
\text { Versus: Treated maize farmers }\end{array}$ & 0.63 & 0.09 & 6.86 & 0.000 & $0.45-0.80$ \\
\hline \multicolumn{7}{|c|}{ Nearest neighbor matching estimator } \\
\hline \multirow{3}{*}{$\begin{array}{l}\text { Average treatment effect } \\
\text { (ATE) } \\
\text { Rice }\end{array}$} & Rice productivity & Coef. & $\begin{array}{l}\text { AI. robust } \\
\text { Std. err }\end{array}$ & $Z$ & $P>|z|$ & ( $95 \%$ conf. interval) \\
\hline & Access to agricultural credit & & & & & \\
\hline & $\begin{array}{l}\text { Non-treated rice farmers } \\
\text { Versus: Treated rice farmers }\end{array}$ & 0.09 & 0.28 & 0.35 & 0.729 & $-0.52-0.85$ \\
\hline \multirow{2}{*}{$\begin{array}{l}\text { Average treatment effect } \\
\text { (ATE) } \\
\text { Maize }\end{array}$} & Access to agricultural credit & Coef. & $\begin{array}{l}\text { AI. robust } \\
\text { Std. err }\end{array}$ & $Z$ & $P>|z|$ & [95\% conf. interval) \\
\hline & $\begin{array}{l}\text { Non-treated maize farmers } \\
\text { Versus: Treated maize farmers }\end{array}$ & 0.69 & 0.83 & 8.27 & 0.000 & $0.52-0.85$ \\
\hline
\end{tabular}

Source: own elaboration

\section{Crop-specific propensity score matching}

The data in Tables 8 and 9 below show the findings from the analysis of the impact of access to agricultural credit on the productivity of rice and maize, with particular focus on the treated and non-treated rice farmers, and the treated and non-treated maize farmers, with and without access to credit. The findings, therefore, reveal whether there was a difference in productivity between the treated and non-treated rice farmers, and between the treated and non-treated maize farmers.

Table 8 presents the findings related to the average treatment effects, and average treatment effects on the treated (ATET) for the treated and non-treated maize and rice farmers using the propensity score matching and nearest neighbor matching techniques. The findings of the propensity score matching technique indicate that there was a significant change in rice productivity ( $p=$ 0.424 ) among the treated and non-treated rice farmers. The findings however revealed that there was a significant difference in productivity $(p=0.000)$ among the maize farmers who accessed agricultural credit and those who did not. The difference in proportions between the treated and non-treated maize farmers was $63.0 \%$ (coef. $=0.63$ ), implying that for every tonne of maize produced by the non-treated farmers, treated farmers produced $62.5 \%$ more $(630 \mathrm{~kg})$.

The findings from the average treatment effects on the treated and non-treated maize and rice farmers using the nearest neighbor matching also indicate no significant difference in productivity $(p=0.729)$ between the rice farmers who accessed credit (treated) and those who did not access credit (non-treated). However, there was a significant difference in productivity $(p=0.000)$ among maize farmers who accessed agricultural credit and those who did not. The difference in proportions between the treated and non-treated maize farmers was $69.0 \%$ (coef. $=0.69$ ), implying that for every tonne of maize produced by the non-treated farmers, treated farmers produced $69 \%$ more $(690 \mathrm{~kg})$.

Examining the Average Treatment Effect on the Treated (ATET) using PSM, the findings in Table 9 above reveal that there was no significant difference in 
Taremwa, N. K., Macharia, I., Bett, E., Majiwa, E. (2021). Impact of agricultural credit access on agricultural productivity among maize and rice smallholder farmers in Rwanda. J. Agribus. Rural Dev., 1(59), 39-58. http://dx.doi.org/10.17306/ J.JARD.2021.01341

Table 9. Average treatment effects on the treated (ATET) using the propensity score matching estimator

\begin{tabular}{|c|c|c|c|c|c|c|}
\hline \multicolumn{7}{|c|}{ Propensity score matching estimator } \\
\hline $\begin{array}{l}\text { Average treatment effect on } \\
\text { the treated (ATET) }\end{array}$ & Rice productivity & Coef. & $\begin{array}{l}\text { AI. robust } \\
\text { Std. err }\end{array}$ & $Z$ & $P>|z|$ & {$[95 \%$ conf. interval $)$} \\
\hline Rice & $\begin{array}{l}\text { Non-treated rice farmers } \\
\text { Versus: Treated rice farmers }\end{array}$ & 0.07 & 0.12 & 0.59 & 0.557 & $-0.16-2.99$ \\
\hline Maize & $\begin{array}{l}\text { Non-treated maize farmers } \\
\text { Versus: Treated maize farmers }\end{array}$ & 0.62 & 0.09 & 6.24 & 0.000 & $0.42-0.81$ \\
\hline \multicolumn{7}{|c|}{ Nearest neighbor matching estimator } \\
\hline \multirow{3}{*}{$\begin{array}{l}\text { Average treatment effect on } \\
\text { the treated (ATET) } \\
\text { Rice }\end{array}$} & Rice productivity & Coef. & $\begin{array}{l}\text { AI. robust } \\
\text { Std. err }\end{array}$ & $Z$ & $P>|z|$ & [95\% conf. interval] \\
\hline & Access to agricultural credit & & & & & \\
\hline & $\begin{array}{l}\text { Treated rice farmers } \\
\text { Versus: Non-treated rice farmers }\end{array}$ & 0.04 & 0.31 & 0.11 & 0.909 & $-0.57-0.65$ \\
\hline \multirow{2}{*}{$\begin{array}{l}\text { Average treatment effect on } \\
\text { the treated (ATET) } \\
\text { Maize }\end{array}$} & Access to agricultural credit & Coef. & $\begin{array}{l}\text { AI. robust } \\
\text { Std. err }\end{array}$ & $Z$ & $P>|z|$ & {$[95 \%$ conf. interval $)$} \\
\hline & $\begin{array}{l}\text { Treated maize farmers } \\
\text { Versus: Non-treated maize farmers }\end{array}$ & 0.68 & 0.09 & 7.95 & 0.000 & $0.51-0.85$ \\
\hline
\end{tabular}

Source: own elaboration.

productivity ( $p=0.557)$ between the treated rice farmers and non-treated ones. However, there was a significant difference in productivity $(p=0.000)$ among the treated maize farmers and non-treated ones. For every tonne of maize obtained by the non-treated smallholder maize farmers, the treated smallholder farmers obtain an extra 620 kilograms.

Using the Nearest Neighbor Matching Estimator, the average treatment effect on the treated indicated that there were similarities and slight differences in treatment coefficients between ATE and ATET findings, given that both estimations from PSM and NNM for ATE and ATET revealed that access to agricultural credit did not have a significant effect on agricultural productivity among the treated smallholder rice farmers. There was no statistically significant difference in agricultural productivity between the rice farmers who accessed credit and those who did not access credit $(P=$ 0.909). However, there was a statistically significant difference $(P=0.000)$ in productivity among maize farmers who accessed agricultural credit and those who did not. The difference in proportions between the treated and non-treated maize farmers was $68 \%$ (coef. $=0.68$ ), implying that for every tonne of maize produced by the non-treated farmers, treated farmers produced $68.0 \%$ more $(681 \mathrm{~kg})$. In other words, for every tonne of maize obtained by the non-treated smallholder maize farmer's, the treated smallholder farmers obtain an extra 681 kilograms (coef. $=0.68, p=0.000$ ).

\section{Additional descriptive analyses to support variations in the impact of credit on the productivity of maize and rice among the treated farmers}

The findings in this section have been included to support the findings in Table 9 above. Particularly, first to support the finding that agricultural credit had no significant impact on rice productivity, and to identify the source of the difference in the impact of agricultural credit access on maize and rice production through input usage. The findings shown in Table 9 were obtained following a cross-tabulation of treatment characteristics and area of land owned plus agricultural inputs that were used by the treated smallholder maize and rice farmers during the previous agricultural season over which productivity was assessed.

In Table 10 above, it is shown that in the group of the treated rice farmers, only $5.6 \%$ of them had cultivated 
Taremwa, N. K., Macharia, I., Bett, E., Majiwa, E. (2021). Impact of agricultural credit access on agricultural productivity among maize and rice smallholder farmers in Rwanda. J. Agribus. Rural Dev., 1(59), 39-58. http://dx.doi.org/10.17306/ J.JARD.2021.01341

Table 10. Comparisons of the treated maize and rice farmers in terms of area of land and inputs used in the previous agricultural season

\begin{tabular}{lcccccc}
\hline \multirow{2}{*}{ Type of farmers } & \multicolumn{5}{c}{ Area of land owned } \\
\cline { 2 - 6 } & $0-0.1$ ha & $0.1-0.19$ ha & $0.2-0.49$ ha & $0.5-0.99$ ha & $1-1.99$ ha & $2-5$ ha \\
\hline Treated smallholder rice farmers & $4(22.2 \%)$ & $2(11.1 \%)$ & $2(11.1 \%)$ & $9(50.0 \%)$ & $1(5.6 \%)$ & $0(0.0 \%)$ \\
Treated smallholder maize farmers & $6(15.4 \%)$ & $4(10.3 \%)$ & $11(28.2 \%)$ & $14(35.9 \%)$ & $3(7.7 \%)$ & $1(2.6 \%)$ \\
Count & 10 & 6 & 13 & 23 & 4 & 1 \\
\hline & Agricultural inputs used in the previous season & organic, and & inorganic \\
& organic & inorganic & pesticide & ferganic & fertilizer and \\
& fertilizer & fertilizer & & pesticides & pesticides \\
\hline Treated smallholder rice farmers & $14(70.0 \%)$ & $4(20.0 \%)$ & $1(5.0 \%)$ & $1(5.0 \%)$ & $0(0.0 \%)$ & $20(\%)$ \\
Treated smallholder maize farmers & $20(47.6 \%)$ & $14(33.3 \%)$ & $0(0.0 \%)$ & $6(14.3 \%)$ & $2(4.8 \%)$ & $42(\%)$ \\
Count & 34 & 18 & 1 & 7 & 2
\end{tabular}

Source: own elaboration.

more than 1 hectare of rice in the previous season, compared to $10.3 \%$ of the treated maize farmers. The findings further indicate that in the group of the treated rice farmers, only $5 \%$ of them used organic fertilizers, inorganic fertilizers and pesticides in the previous season, as compared to $14.3 \%$ of the treated maize farmers.

\section{DISCUSSION OF THE RESULTS}

A significant effect of credit (treatment) on maize and rice productivity among farmers in the Western and Eastern provinces of Rwanda was observed, keeping all the other factors constant. This finding agrees with the suppositions of the economic development theory by Wiggins (2006) in which it is theorized that agricultural development approaches, such as the provision of agricultural credit to farmers, can enable farmers to invest in improved agriculture, which can lead to higher agricultural productivity. The finding is also consistent with findings by Mamudu (2016) in Ghana, Owusu (2017) in Ghana, Musinguzi (2017) in Uganda, Gonzalez and Moser (2015) in Brazil, Nuhu et al. (2014) in Ghana, Teka and Lee (2019), Chandio et al. (2018) in Pakistan, Beaman et al. (2014) in Mali, and Zakaria (2019) in South Asia.

The findings revealed that productivity among the treated smallholder farmers was 0.4 times higher $(0.44)$ than that of the non-treated smallholder farmers. This finding implies that for every tonne of rice or maize produced by a smallholder farmer who had no access to credit, those who had access to agricultural credit produced 400 extra kilograms of the said cereals. This finding is dissimilar but reveals a higher increase than that found by Mamudu (2016) who reported that the extra increase in productivity among smallholder farmers was only $100 \mathrm{~kg}$. The difference in the findings could be due to confounding factors, notably the area of land, and differences in treatment characteristics among farmers in the current study and farmers in the study by Mamudu (2016). Treated farmers in the study by Mamudu (2016) were reported to have received relatively lower amounts of credit, and the majority had smaller areas of land than farmers who participated in the current study, which most probably resulted in lower productivity among farmers in the other study. The findings are also inconsistent with many other studies that reported higher increments in productivity due to credit access. The difference in the findings may also be related to the difference in the types of crops that were considered in the current study and other studies (Nuhu et al., 2014; Chandio and Jiang, 2018; Owusu, 2017). This is premised on the fact that some crops require input provision for a longer period of time than others. For instance, as far as cassava 
Taremwa, N. K., Macharia, I., Bett, E., Majiwa, E. (2021). Impact of agricultural credit access on agricultural productivity among maize and rice smallholder farmers in Rwanda. J. Agribus. Rural Dev., 1(59), 39-58. http://dx.doi.org/10.17306/ J.JARD.2021.01341

and rice are concerned, , the latter requires inputs over a longer period compared to the former, which can be limited by credit. Therefore, it can happen that even with access to finance, cassava farmers who received a credit that was possibly subject to a loan ceiling, may have had some credit shortage, compared to rice farmers, which leds to a difference in productivity.

The impact of access to credit on maize and rice productivity depends on the merits of such a credit when in the hands of a farmer. One of these is the use of credit to purchase modern agricultural inputs ranging from fertilizer to improved seed and the cultivation of more land rented from others, which enables the farmer to produce the crops. Agricultural credit also acts as a potent safety net against environmental/climatic change effects since a farmer can, for example, use an irrigation system during periods of drought, thus ensuring sufficient water supply for more water-intensive cereals such as maize and rice.

However, it is also important to note that the difference in maize and rice tonnage among smallholder farmers who had accessed credit and those who had no access to it was $400 \mathrm{~kg}$, which, although significant, could have been even higher, as has been reported in some studies. The 400-kilogram difference could be one of the reasons why despite the evident impact of credit on maize and rice productivity, Rwanda still has a high food import bill (USDA, 2018); especially for maize and rice, and why local production is still not sufficient to meet the growing local demand for domestic consumption (Muvunyi, 2019; Gahigi, 2019). This means that as credit access to smallholder farmers has increased, agricultural productivity has also increased, but it is not high enough to meet the current demand for both cereal crops, since their production is not yet at optimal levels. Thus, there could be inherent challenges in accessing and using agricultural credit that prevent its impact on agricultural productivity from reaching maximum levels. One of these is loan ceilings that some financial institutions in Rwanda have instated, thus curtailing access to the amounts of credit needed by smallholder farmers. This results in farmers accessing smaller amounts of credit that in the long run are insufficient for the purchase of appropriate amounts of agricultural inputs, which affects the desired productivity.

Other possible confounders of the 430-kg difference were revealed during the characterization process of the farmers in which characteristics such as a small area of land and household size were taken into account. These two characteristics can be significant hurdles to the achievement of highly substantial agricultural productivity, even when agricultural credit is accessed. Those hurdles can be more pronounced when a farmer who has less than a hectare of land and relatively little family labor available accesses credit but does not invest in basic mechanization for small plots, improved seed, other pre-harvest technologies or hired labor, which has been found to be the case in many countries (Mottaleb, 2018; Mottaleb, 2017; Yamauchi, 2016; Mottaleb, 2016). It is possible, therefore, that smallholder farmers in Rwanda who have managed to access agricultural credit have not yet embraced the use of modern agricultural technologies and systems that can boost agricultural production irrespective of the plot sizes of labor they have.

The findings obtained from the analysis of the impact of agricultural credit on crop-specific productivity (maize and rice) (Table 8) further showed that while there was no difference in productivity among the treated and non-treated farmers $(P=0.149)$, the difference was evident among maize farmers. The treated maize farmers produced $68.1 .2 \%$ more maize $(680$ $\mathrm{kg})($ Coef. $=0.68)$, compared to the non-treated maize farmers, whereas the treated rice farmers did not produce amounts of rice significantly different from those produced by the non-treated rice farmers. This finding is inconsistent with findings by Temitope et al. (2019), Bidzakin et al. (2019), Ojo et al. (2019), and Lawal et al. (2019) who indicated that agricultural credit access had a significant impact on rice productivity. However, there are a number of reasons for the difference between the findings of the other studies and those of the current study. One of such reasons is that in all of the aforementioned studies which reported impact on rice production, access to credit among smallholder rice farmers was considerably higher than that among rice farmers that were sampled in this study. That alone implies that the combined impact of credit on productivity among farmers in those studies was higher. Secondly, the majority of smallholder rice farmers, especially in Nigeria (Temitope et al., 2019; Bidzakin et al., 2019; Ojo et al., 2019; Lawal et al., 2019) had significantly larger areas of land ( $>1$ hectare), as opposed to smallholder rice farmers in the Eastern and Western provinces, the majority of whom cultivated less than 1 hectare of land. This difference in the area of land alone certainly resulted in higher productivity of rice farmers in the other studies, given that the area of land is an established independent factor 
of agricultural productivity (Chandio et al., 2017) with a directly proportional relationship between them.

As for the difference in productivity between the treated maize farmers and the treated rice farmers, the findings in Table 9 provided data to support the finding. The table shows that the treated smallholder rice farmers generally cultivated smaller areas of land compared to maize farmers, and also used less fertilizers, as compared to maize farmers. In other words, a smaller proportion of rice farmers who accessed credit bought and used fertilizers and pesticides (5\%), compared to maize farmers $(10.3 \%)$, which clearly affected the productivity of rice farmers given the proven effect of fertilizers on cereal yields (Abednego et al., 2019; Yousaf et al., 2017).

The relatively higher purchase and use of fertilizers and pesticides by the maize farmers who accessed credit (Table 9) also partly explain the finding that the treated maize farmers produced $68.0 \%$ more maize $(680$ $\mathrm{kg})($ Coef. $=0.68)$, compared to the non-treated farmers. The use of fertilizers alone allows for the provision of organic sources of plant nutrients, especially manure to build soil organic matter (SOM) which ensures that cultivated soils are rich in nutrients, and prevents nutrient deficiencies in maize and secures high yields. Secondly, in the past two years, maize farmers in Rwanda have been affected by the fall armyworm, with a greater effect on smallholder farmers who did not use pesticides. Therefore, it is plausible to postulate that, compared to the non-treated maize farmers, the treated maize farmers had better access to pesticides, applied them more, and hence were less affected by that pest.

\section{IMPLICATIONS FOR RESEARCH AND PRACTICE}

Access to agricultural credit has undoubtedly had an impact on the productivity of smallholder maize and rice farmers in the Eastern and Western provinces of Rwanda. However, it is evident that this impact, though statistically significant, is still sub-optimal, given that the difference in yields among farmers with access to credit and farmers without access to credit was about 440 kilograms per tonne. That is, for every tonne produced by farmers without credit access, farmers with credit access produce only $440 \mathrm{~kg}$ more than those who did not receive credit. Thus, there is a need for the government and agricultural policy-makers in Rwanda to develop the ways of boosting productivity among maize and rice farmers through improving their access to agricultural credit. However, whereas generic assessment of the impact of agricultural credit on agricultural productivity revealed a positive effect of the credit, crop-specific assessment proved otherwise. Agricultural credit access was found to have no significant impact on rice productivity among the treated rice farmers, as opposed to the treated maize farmers. This finding, though reliable and valid, could be further verified by future incountry studies that should be conducted in other provinces and districts with high numbers of rice farmers. Nonetheless, this should be a signal to officials in the line ministry who are currently advocating augmented rice production in the country, as rice is one of the principal crops of focus in the country. Whereas government through the line ministry has supported the financial inclusion of rice farmers, it is evident that impact is yet to be realized, and thus they need to intervene before long, with emphasis on the promotion of the purchase and use of improved seeds and direct financing.

A greater impact of agricultural credit on agricultural productivity can be achieved via the creation of an enabling environment that can allow farmers who seek credit to obtain higher amounts of it, for instance by removing loan ceilings. This can be encouraged by the central bank of Rwanda in conjunction with associations of finance institutions in the country. It will be of particularly great assistance to rice farmers, given that, as compared to maize farming, rice farming is more labor- and cash-intensive. A greater impact of agricultural credit can be achieved among rice farmers by the adoption by credit providing institutions of direct financing strategies in which they start providing agricultural inputs to rice farmers as opposed to only liquid credit, or at least provide credit management education to smallholder rice farmers before granting credit to them. That might help ensure that part of the credit accessed by rice farmers is allocated to the purchase of inputs including fertilizers and pesticides, which may certainly help bolster their productivity.

There is also a need for intensive farmer education programs to be sanctioned and implemented by the Ministry of Agriculture and its partners in the private sector. That will be for purposes of educating farmers with loan use experience and those who will seek loans in the future about loan management and good investment practices in the context of agribusiness. Doing so may 
Taremwa, N. K., Macharia, I., Bett, E., Majiwa, E. (2021). Impact of agricultural credit access on agricultural productivity among maize and rice smallholder farmers in Rwanda. J. Agribus. Rural Dev., 1(59), 39-58. http://dx.doi.org/10.17306/ J.JARD.2021.01341

enable farmers who access credit to invest it in modern farming techniques that can boost productivity, regardless of whether the farmer who received a loan has less than a hectare of land or whether he has a family labor source or not.

\section{CONCLUSION}

Agricultural credit access has had an impact on agricultural productivity among maize and rice smallholder farmers in the Eastern and Western provinces, however with a more significant impact on maize, as opposed to rice.

\section{FUTURE RESEARCH}

It would be worthwhile for other studies to be conducted to assess the impact of access to agricultural credit on agricultural productivity of smallholder maize and rice farmers, however with a focus on both agricultural seasons in Rwanda (A and B), during the assessment of crop yields. Such studies may certainly further confirm the findings of the current study.

\section{ACKNOWLEDGMENTS}

The research reported in this publication was supported by the Regional Universities Forum for Capacity Building in Agriculture (RUFORUM). The authors sincerely acknowledge the financial support. The authors are also thankful to the many farmers who participated in the survey for providing very useful information.

\section{REFERENCES}

Abednego, K., David, K., Rebbie, H., Bashir, J., Gudeta, W., Sileshi. B. (2019). Sustainable intensification with cereallegume intercropping in Eastern and Southern Africa. Sustainability, 11(10), 2891; doi: 10.3390/su11102891

Access to Finance Rwanda (2017). Annual report summary. Kigali, Rwanda.

Access to Finance Rwanda (2019). National financial inclusion strategy for Rwanda 2019-2024. Kigali, Rwanda.

AGRA (2017). Doubling productivity and incomes of smallholder farmers in Africa. Retrieved April 26 2020 from: https://agra.org/doubling-productivity-and-incomes-ofsmallholder-farmers-in-africa/

Akoété, E.A., Ablamba, A J. (2019). Agricultural credit and its impact on the productivity of certain cereals in Togo.
Emerg. Market. Fin. Trade, 1-17.DOI: 10.1080/1540496X. 2019.1602038

Akram, W., Hussain, Z., Ahmad, N., Hussain, I. (2013). Does agriculture credit affect production efficiency? Frontier production function approach. Pakis. Econ. Soc. Rev., 51(2), 179-190.

Akudugu, M. (2016). Agricultural productivity, credit and farm size nexus in Africa: A case study of Ghana. Agric. Fin. Rev., 76(2), 288-308. https://doi.org/10.1108/AFR12-2015-0058;

Ali, D.A., Deininger, K., Duponchel, M. (2014). Credit constraints and agricultural productivity: Evidence from rural Rwanda. J. Dev. Stud., 50(5), 649-665.

Andae, G. (2020). Maize production shortfall sets the stage for imports. Retrieved $28^{\text {th }}$ April 2020 from: https://www. theeastafrican.co.ke/business/Food-agency-asks-State-toimport-2m-bags-of-maize/2560-5486688-op7fsl/index. html

Awotide, B.A., Abdoulaye, T., Alene, A., Manyong, V.M. (2015). Impact of Access to Credit on Agricultural Productivity: Evidence from Smallholder Cassava Farmers in Nigeria. A Contributed paper Prepared for Oral Presentation at the International Conference of Agricultural Economists (ICAE) Milan, Italy, August 9-14.

Baffoe, G., Matsuda, H., Masafunii, N., Akiyama, T. (2015). The dynamics of rural credit and its impact on agricultural productivity: an empirical study in Rural Ghana. OIDA Int. J. Sust. Dev., 7(5), 19-34.

Baker, J.L. (2000). Evaluating the impact of development projects on poverty: A handbook for practitioners. Washington DC: World Bank Publications. The World Bank, number 13949.

Beaman, L., Karlan, D., Thuysbaert, B. (2014). Saving for a (not so) rainy day: A randomized evaluation of savings groups in Mali. NBER Working Paper Series 20600; www.nber.org/papers/w20600

Becerril, J., Abdulai, A. (2010). The impact of improved maize varieties on poverty in Mexico: A propensity scorematching approach. World Dev., 38(7), 1024-1035.

Bhatia, S.S. (1967). A New Approach to Measure Agricultural Efficiency in Uttar Pradesh. Economics Geography, 43, 224-260.

Bidzakin, J.K., Simon, C., Fialor, D., Awunyo, V., Iddrisu, Y. (2019).Impact of contractfarming on rice farmperformance: Endogenous switching regression. Cogent Econ. Fin., 7(1), 1618229. DOI: 10.1080/23322039.2019.1618229

Caliendo, M., Kopeinig, S. (2008). Some practical guidance for the implementation of propensity score matching. IZA Discussion Paper No. 1588. The Institute for the Study of Labor (IZA) in Bonn. 
Taremwa, N. K., Macharia, I., Bett, E., Majiwa, E. (2021). Impact of agricultural credit access on agricultural productivity among maize and rice smallholder farmers in Rwanda. J. Agribus. Rural Dev., 1(59), 39-58. http://dx.doi.org/10.17306/ J.JARD.2021.01341

Chandio, A.A., Jiang, Y. (2018). Determinants of credit constraints: Evidence from Sindh, Pakistan. Emerg. Market. Fin. Trade, 54(15), 3401-3410.

Chandio, A.A., Yuansheng, J., Koondher, M.A. (2015). Raising maize productivity through agricultural credit A: Case Study of Commercial Banks in Pakistan. Eur. J. Bus. Manag., 7(32), 159-165.

Chandio, A.A., Yuansheng, J., Wei, F., Rehman, A., Liu, D. (2017). Farmers' access to credit: Does collateral matter or cash flow matter? Evidence from Sindh, Pakistan, Cogent Econ. Fin. Retrieved from: https://doi.org/10.1080/23322 039.2017.1369383

Devotha, G., Nyambo, E.T., Luhanga, Z.Q.Y. (2019). A review of characterization approaches for smallholder farmers: Towards predictive farm typologies. Sci. World J., 6121467; https://doi.org/10.1155/2019/6121467.

DeVries, J. (2017). Doubling productivity and incomes of smallholder farmers in Africa. Alliance for a Green Revolution in Africa. Retrieved from: https://agra.org/news/ doubling-productivity-and-incomes-of-smallholder-farmers-in-africa/

Duy, V.Q. (2015). Access to credit and rice production efficiency of rural households in the Mekong Delta. Sociol. Anthrop., 3(9), 425-433.

FAO (2017). The future of food and agriculture - Trends and challenges. Rome: FAO. Retrieved from http://www.fao. org/3/a-i6583e.pdf

FAO (2018). Credit to agriculture. Retrieved from http:// www.fao.org/economic/ess/investment/credit/en/

FAO (2018). Rice market monitor (t. XXI). Retrieved from: http://www.fao.org/3/I9243EN/i9243en.pdf

FAO (2019). Food outlook - biannual report on global food markets - November 2019. Rome: FAO.

Friedlander, D., Robins, P.K. (1995). Evaluating program evaluations: Evidence on commonly used non-experimental methods. Am. Econ. Rev., 85(4), 923-937.

Gahigi, M.K. (2019). Despite high rice production, imports needed. Rwanda Today. https://rwandatoday.africa/business/Despite-high-rice-production-imports-needed-/4383192-4386654-q8ey3c/index.html

Gonzalez, L., Moser Barbosa, R. (2015). Green microfinance in Southern Brazil: The case of the cresol system. doi: http://dx.doi.org/10.1590/0034-7612134039

GoR (Government of Rwanda). (2013). National rice development strategy (2011-2018). Retrieved from: https:// riceforafrica.net/images/stories/PDF/rwanda_revised aug2013.pdf

Krejcie, R.V., Morgan, D.W. (1970). Determining sample size for research activities. Educ. Psychol. Meas., 30, 607-610.

Lawal, A.I., Olayanju, A.T., Ayeni, J., Olaniru, O.S. (2019). Impact of bank credit on agricultural productivity: Empiri- cal evidence from Nigeria (1981-2015). Int. J. Civil Eng. Technol., 10(2), 113-123.

Lowder, S.K., Skoet, J., Raney, T. (2016). The number, size, and distribution of farms, smallholder farms, and family farms worldwide. World Dev., 87, 16-29. https://doi.org/ 10.1016/j.worlddev.2015.10.041

Mamudu, A.A. (2016). Agricultural productivity, credit and farm size nexus in Africa: a case study of Ghana. Agric. Credit Rev., 76(2), 288-308.

Mendola, M. (2007). Agricultural technology adoption and poverty reduction: A propensity-score matching analysis for rural Bangladesh. Food Pol., 32(3), 372-393. Retrieved from: https://doi.org/10.1016/j.foodpol.2006.07.003

Mita, B., Sanzidur, R., Shunbo. Y. (2019). Growth in agricultural productivity and its components in Bangladeshi regions (1987-2009): An application of bootstrapped data envelopment analysis (DEA). Economies, 7(2), 37. doi: 10.3390/economies 7020037

Mottaleb, K.A. (2018). Perception and adoption of a new agricultural technology: Evidence from a developing country. Techn. Society, 55, 126-135

Mottaleb, K.A., Krupnik, T.J., Erenstein, O. (2016). Factors associated with small-scale agricultural machinery adoption in Bangladesh: Census findings. J. Rural Stud., 46, 155-168. Retrieved from: https://dx.doi.org/10.1016/j. jrurstud.2016.06.012

Mottaleb, K.A., Rahut, D.B., Akhter, A., Bruno, G., Erenstein, O. (2017). Enhancing smallholder access to agricultural machinery services: Lessons from Bangladesh. J. Dev. Stud., 53(9), 1502-1517. https://dx.doi.org/10.1080/0022 0388.2016.1257116

Musinguzi, I. (2017). The impact of access to agricultural services on maize productivity in Uganda. Doctoral Dissertation. Strathmore University.

Muvunyi, L. (2019). Maize shortage looms despite bumper harvest. Retrieved April 28 2020 from: http://rwandatoday.africa/news/Maize-shortage-looms-despite-bumperharvest/4383214-5102248-r3d1cqz/index.html

NISR (National Institute of Statistics of Rwanda). (2019). Seasonal agricultural survey 2019. Annual report. Retrieved from http://www.statistics.gov.rw/publication/ seasonal-agricultural-survey-2019-annual-report

Nuhu, E., Inusah, A.H., Ama, G.R., Sano, Z.M. (2014). Impact analysis of microfinance on crop production in Ghana. Int. J. Acad. Res. Account. Fin. Manag. Sci., 4(3), 97-108. doi: 10.6007/IJARAFMS/v4-i3/1025

Ojo, T.O., Baiyegunhi, L.J.S., Salami, A.O. (2019). Impact of credit demand on the productivity of rice farmers in South West Nigeria. J. Econ. Behav. Stud. AMH Int., 11(1), 166-180. 
Taremwa, N. K., Macharia, I., Bett, E., Majiwa, E. (2021). Impact of agricultural credit access on agricultural productivity among maize and rice smallholder farmers in Rwanda. J. Agribus. Rural Dev., 1(59), 39-58. http://dx.doi.org/10.17306/ J.JARD.2021.01341

Owusu S. (2017). Effect of access to credit on agricultural productivity: Evidence from cassava farmers in the Afigya-Kwabre District of Ghana. Int. J. Innov. Res. Soc. Sci. Strat. Manag. Techn., 4(2).

Rizwan, M.Q., Ping, S., Iram, A., Nazir, Q., Wang. (2019). Why and for what? An evidence of agriculture credit demand among rice farmers in Pakistan. ADBI Working Paper 995. Tokyo: Asian Development Bank Institute. Retrieved from: https://www.adb.org/publications/why-whatevidence-agriculture-credit-demand-rice-farmers-pakistan

Rosenbaum, P.R., Rubin, D.B. (1983). The central role of the propensity score in observational studies for causal effects. Biometrika, 70(1), 41-55. Retrieved https://dx.doi. org/10.1093/biomet/70.1.41

Sihlobo,W.(2019).Africa:Afterfloods, Zimbabweand Mozambique face huge maize shortfalls. Retrieved $23^{\text {rd }}$ Oct 2019 from: https://allafrica.com/stories/201906200176.html

Sossou, C.H., Noma, F., Yabi, J.A. (2014). Rural credit and farms efficiency: Modelling farmers credit allocation decisions, evidences from Benin. Econ. Res. Int., 309352; http://dx.doi.org/10.1155/2014/309352.

Teka, A.M., Lee, S.K. (2019). The impact of agricultural package programs on farm productivity in Tigray-Ethiopia: Panel data estimation. Cogent Econ. Fin., 7, 1631987. Retrieved from: https:/www.cogentoa.com/article/10.1080/ 23322039.2019.1631987

Temitope, O., Baiyegunhi, L., Salami, O. (2019). Impact of credit demand on the productivity of rice farmers in South West Nigeria. J. Econ. Beh. Stud., 11(10), 166-180; 10.22610/jebs.v11i1(J).2757

USAID (2018). Agriculture and food security. Rwanda. Retrieved from 9 September, 2020. https:/www.usaid.gov/ rwanda/agriculture-and-food-security
USAID (2019). Agriculture and food security. Retrieved April $28^{\text {th }} 2020$ from: https://www.usaid.gov/east-africa-regional/agriculture-and-food-security

Wiggins, E. (2006). Bank credit accessibility and sectoral output performance in a deregulated financial market economy: Empirical evidence from Nigeria. J. Fin. Bank Manag., 1(2), 36-59.

World Bank (2019). Agriculture finance \& agriculture insurance. Retrieved April $28^{\text {th }} 2020$ from: https://www.worldbank.org/en/topic/financialsector/brief/agriculture-finance

World Economic Forum (2016). Five ways to reduce poverty among smallholder farmers. Retrieved April $27^{\text {th }} 2020$ from: https:/www.weforum.org/agenda/2016/03/5-waysto-reduce-poverty-among-smallholder-farmers/

Yamauchi, F. (2016). Rising real wages, mechanization and growing advantage of large farms: Evidence from Indonesia. Food Policy, Elsevier, 58(C), 62-69.

Ye, H., Lin, S. (2009). Does inflation targeting make a difference in developing countries? J. Dev. Econ., 89(1), 118-123.

Yousaf, M., Li, J., Lu, J. (2017). Effects of fertilization on crop production and nutrient-supplying capacity under rice-oilseed rape rotation system. Sci. Rep., 7, 1270; https://doi. org/10.1038/s41598-017-01412-0

Zakaria, M., Jun, W., Khan, M.F. (2019). Impact of financial development on agricultural productivity in South Asia. Agric. Econ. Czech, 65, 232-239.

Zenawi, G., Mizan, A. (2019). Effect of nitrogen fertilization on the growth and seed yield of sesame (Sesamum indicum L.). Int. J. Agron., 5027254; https://doi.org/10.1155/ 2019/5027254 